\title{
PROLONGED HYPERPLASMINEMIA WITH MITOMYCIN C IN RABBITS
}

\author{
REVERSIBLE DISAPPEARANCE OF TISSUE ACTIVATOR \\ IN PARENCHYMA OF KIDNEY
}

\author{
UTAKO OKAMOTO and YUMIKO TAKADA \\ Department of Physiology, School of Medicine, \\ Keio University, Tokyo, Japan
}

(Received for publication July 31, 1964)

The several workers have reported that the transient hyperplasminemia is caused by the administration of adrenalin(1), acetylcholin(2), pyrogen(3) or nicotinic acid(4). Besides, it has been well known that some bacterial products such as streptokinase ${ }^{(5)}$ and staphylokinase ${ }^{(6)}$ produce hyperplasminic state.

However, the mechanism of hyperplasminemia in man seems to be more complicated. It is generally supposed that releasing of the tissue activator into the blood stream can be an essential cause of hyperplasminemia in patients.

The present paper reports that Mitomycin C, an antitumor substance, produces a long continued hyperplasminemia when injected intravenously to rabbits. It is also reported here that the administration of Mitomycin $\mathrm{C}$ causes a marked decrease of tissue activator in kidney parenchyma, and that the decreased tissue activator is reversed towards normal after ceasing administration of Mitomycin $\mathrm{C}$.

\section{MATERIALS AND METHODS}

Animals under experiment: Male rabbits, weighing $2.5-3 \mathrm{~kg}$ were used for experiments.

Assays of plasmin activity in blood: Fibrinolytic activity in the blood of rabbits was assayed by determination of lysis time of fibrin clot. The method of Lewis and Ferguson(7) was partially modified as follows. A $0.5 \mathrm{ml}$ of $0.2 \%$ fibrinogen solution, $1.0 \mathrm{ml}$ of borate saline buffer solution, $0.5 \mathrm{ml}$ of euglobulin fraction solution of the test serum and $0.2 \mathrm{ml}$ of $20 \mathrm{units} / \mathrm{ml}$ thrombin solution were admixed together, and the reaction mixture was incubated at $37^{\circ} \mathrm{C}$. The lysis time of formed fibrin clot was measured in minutes.

Assays of plasminogen activator activity: Activity of plasminogen activator 
was determined using unheated (standard) and heated plates by the methods of Astrup et $a l^{(8)}$ and Lassen(9). Tissue extract of $0.03 \mathrm{ml}$ was placed on both heated and unheated plates, and the plates were incubated for 18 hours at $37^{\circ} \mathrm{C}$. The lytic zone was recorded as the product of two perpendicular diameters $\left(\mathrm{mm}^{2}\right)$.

Extraction of tissue activator: The fresh tissue, after homogenized with $2 \mathrm{M} \mathrm{KCl}$ or $30 \%$ sucrose solution of ten times, was extracted at $0^{\circ} \mathrm{C}$ for 2 hours ${ }^{(10)}$. Supernatant was separated after centrifugation for 10 minutes at 3,000 r.p.m. at $0^{\circ} \mathrm{C}$, and the supernatant was used for assay.

Assays of fibrinogen content: Fibrignogen content in blood was estimated according to Gram(11).

Assays of plasmin inhibitor: The inhibitory action of the inhibitor solution was estimated against plasmin preparation on fibrin plates.

Extraction of tissue inhibitor: The inhibitor was prepared by the method of Astrup \& Albrechtsen (1957)(12). Fresh kidney parenchyma was extracted at $0^{\circ} \mathrm{C}$ for 2 hours, after homogenizing with $2 \mathrm{M} \mathrm{KSCN}$ of 10 times of the tissue sample. Supernatant was separated after centrifugation and diluted 8 times with water and brought to $\mathrm{pH} 1.0$ with $1 \mathrm{~N} \mathrm{HCl}$. After separation by centrifugation $0.1 \mathrm{M}$ sodium tungstate $(0.1$ vol.) was added to the supernatant. After standing for 30 minutes, at room temperature, the precipitate was separated by centrifugation and redissolved to the original volume in borate buffer.

Euglobulin solution: The euglobulin fraction was obtained by dilution and isoelectric precipitation. Rabbits plasma was diluted with 20 times pure water and added $0.5 \%$ acetic acid to adjust $\mathrm{pH}$ to 5.2 . The precipitate was resuspended in the borate buffer of same volume as original plasma.

Fibrinogen and Thrombin: Bovine fibrinogen (Cohn's fraction 1 Armour) and Thrombin topical Mochida were used. Borate buffer was used as the solvent of both fibrinogen and thrombin.

Borate saline buffer: Buffer solution, of $\mathrm{pH} 7.75$, containing $\mathrm{H}_{3} \mathrm{BO}_{4} 11.25 \mathrm{~g}$, $\mathrm{NaCl} 2.25 \mathrm{~g}$ and $\mathrm{Na}_{2} \mathrm{~B}_{4} \mathrm{O}_{7} \mathrm{H}_{2} \mathrm{O} \cdot 4.00 \mathrm{~g}$ in $1 l$ was used.

Mitomycin C: Mitomycin C, Kyowa Hakko, was used.

Trypsin: Crystalline trypsin, Mochida was used dissolving in 50\% glycerol solution.

Plasmin: Human plasmin, Thrombolysin Merck Sharp \& Dohme, was used.

\section{RESULTS}

1. Hyperplasminemia produced by the administration of Mitomycin $\mathrm{C}$ in rabbits. 
Mitomycin C (MMC) of $0.16 \mathrm{mg}$ or $0.5 \mathrm{mg} / \mathrm{kg}$ was intravenously injected into 3 rabbits, once a day for 9 days. Blood was withdrawn by venipuncture to estimate the plasmin activity and fibrinogen content. The results shown in table 1 indicated that euglobulin fibrinolytic activity increased in those rabbits, and detailed result of rabbit No. 3 is illustrated in figure 1 . In this case, plasimin activity was remarkably increased in 5 days after starting MMC administration, and it was followed by continuing activation for a week even after ceasing the administration. The content of fibrinogen, however, showed no remarkable change. The rabbit No. 3 died after 24 days since starting MMC administration, although plasmin activity became normal. Autopsy of the rabbit showed macroscopic bleeding in lungs, liver, intestine and kidneys.

Table 1.

Effect of MMC on the blood plasmin activity of rabbits

\begin{tabular}{|c|c|c|c|c|c|c|c|}
\hline \multirow{3}{*}{$\begin{array}{c}\text { Rabbit } \\
\text { No. }\end{array}$} & \multicolumn{6}{|c|}{ Euglobulin fibrinolysis time ( $\mathrm{min}$ ) } & \multirow{3}{*}{ Administration of $\mathrm{MMC}$} \\
\hline & \multirow{2}{*}{$\begin{array}{l}\text { before } \\
\text { admin. }\end{array}$} & \multicolumn{5}{|c|}{ after starting administration (days) } & \\
\hline & & 2 & 5 & 8 & 15 & 17 & \\
\hline 1 & 155 & - & - & 45 & 165 & - & $0.16 \mathrm{mg} / \mathrm{kg}$ daily for 9 days \\
\hline 2 & 165 & - & $\underline{-}$ & 60 & 210 & - & $0.5 \mathrm{mg} / \mathrm{kg}$ daily for 9 days \\
\hline 3 & 140 & 140 & 90 & 75 & 75 & 120 & $0.5 \mathrm{mg} / \mathrm{kg}$ daily for 9 days \\
\hline
\end{tabular}

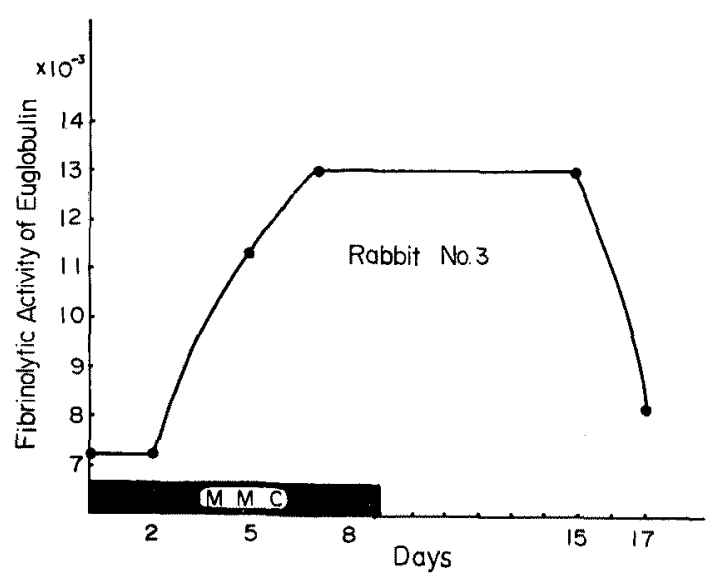

Fig. 1 Effect of administration of MMC on the euglobulin fibrinolysis of a rabbit's blood.

MMC was given intravenously to a rabbit for a period of 9 days in a dose of $0.5 \mathrm{mg} / \mathrm{kg} / \mathrm{day}$. The fibrinolytic activity of euglobulin is plotted as a reciprocal
of lysis time of fibrin clot in minutes.

2. Disappearance of the tissue activator activity of kidney parenchyma by the administration of MMC. 
Table 2.

Disappearance of the tissue activator activity in kidney parenchyma by the MMC administration. (KCl-extracted activator)

\begin{tabular}{|c|c|c|c|c|c|c|c|c|c|}
\hline \multirow{3}{*}{$\begin{array}{l}\text { Solution } \\
\text { used }\end{array}$} & \multirow{3}{*}{$\begin{array}{c}\text { Rabbit } \\
\text { No. }\end{array}$} & \multirow{3}{*}{ Group } & \multicolumn{5}{|c|}{ Standard plate $\left(\mathrm{mm}^{2}\right)$} & \multirow{2}{*}{\multicolumn{2}{|c|}{$\frac{\text { Heated plate }}{\text { Kidney }\left(\mathrm{mm}^{2}\right.}$}} \\
\hline & & & \multicolumn{2}{|c|}{ Kidney } & \multirow{2}{*}{ Heart } & \multirow{2}{*}{ Lung } & \multirow{2}{*}{ Liver } & & \\
\hline & & & Par. & Pelvis & & & & Par. & Pelvis \\
\hline \multirow{13}{*}{$2 \mathrm{M} \mathrm{KCl}$} & 1 & \multirow{7}{*}{$\begin{array}{l}\text { control } \\
\text { group }\end{array}$} & 91 & - & 0 & 0 & 0 & 0 & - \\
\hline & 2 & & 56 & 15 & - & 0 & - & - & 一 \\
\hline & 3 & & 81 & 39 & 0 & 0 & 0 & - & - \\
\hline & 4 & & 204 & 8 & - & - & - & - & 一 \\
\hline & 5 & & 100 & - & - & - & - & 0 & - \\
\hline & 6 & & 166 & - & - & - & - & 0 & - \\
\hline & 7 & & 96 & - & - & - & - & - & - \\
\hline & 8 & \multirow{6}{*}{$\begin{array}{l}\text { MMC } \\
\text { group }\end{array}$} & 0 & 47 & 0 & 0 & 0 & 0 & 0 \\
\hline & 9 & & 0 & 14 & 0 & 0 & 0 & - & - \\
\hline & 10 & & 0 & 18 & 0 & 0 & 0 & - & - \\
\hline & 11 & & 0 & 20 & 0 & 0 & 0 & 一 & - \\
\hline & 12 & & 0 & 95 & - & - & - & - & - \\
\hline & 13 & & 0 & 53 & - & - & - & - & - \\
\hline
\end{tabular}

Table 3.

Disapperance of the tissue activator activity in kidney parenchyma by the MMC administration. (Sucrose-extracted activator)

\begin{tabular}{|c|c|c|c|c|c|c|c|c|c|}
\hline \multirow{3}{*}{$\begin{array}{l}\text { Solution } \\
\text { used }\end{array}$} & \multirow{3}{*}{$\begin{array}{c}\text { Rabbit } \\
\text { No. }\end{array}$} & \multirow{3}{*}{ Group } & \multicolumn{5}{|c|}{ Standard plate $\left(\mathrm{mm}^{2}\right)$} & \multirow{2}{*}{\multicolumn{2}{|c|}{$\frac{\text { Heated plate }}{\text { Kidney }\left(\mathrm{mm}^{2}\right.}$}} \\
\hline & & & \multicolumn{2}{|c|}{ Kidney } & \multirow{2}{*}{ Heart } & \multirow{2}{*}{ Lung } & \multirow{2}{*}{ Liver } & & \\
\hline & & & Par. & Pelvis & & & & Par. & Pelvis \\
\hline \multirow{13}{*}{$\begin{array}{c}30 \% \\
\text { Sucrose }\end{array}$} & 1 & \multirow{7}{*}{$\begin{array}{l}\text { Control } \\
\text { group }\end{array}$} & 105 & - & 0 & 0 & 0 & 0 & - \\
\hline & 2 & & 5 & 60 & - & 0 & 0 & - & - \\
\hline & 3 & & 4 & 56 & 0 & 0 & 0 & - & 一 \\
\hline & 4 & & 35 & 59 & - & - & - & - & - \\
\hline & 5 & & 108 & - & - & - & - & 0 & - \\
\hline & 6 & & 117 & - & - & - & - & 0 & - \\
\hline & 7 & & 64 & $一$ & - & - & - & - & 一 \\
\hline & 8 & \multirow{6}{*}{$\begin{array}{l}\text { MMC } \\
\text { group }\end{array}$} & 0 & 52 & 0 & 0 & 0 & 0 & 0 \\
\hline & 9 & & 0 & 111 & 0 & 0 & 0 & - & -- \\
\hline & 10 & & - & 64 & 0 & 0 & 0 & - & - \\
\hline & 11 & & 0 & 13 & 0 & 0 & 0 & - & - \\
\hline & 12 & & 0 & 51 & - & - & - & - & - \\
\hline & 13 & & 0 & 95 & - & - & - & - & - \\
\hline
\end{tabular}


MMC of $0.5 \mathrm{mg} / \mathrm{kg}$ was intravenously injected into 6 rabbits, once a day for 12 days. On the 15th day after starting MMC injection, animals were bled to death from carotid arteries, and organs were taken out immediately. Seven animals were used as controls. Fresh tissue of kidney, heart, lung and liver was extracted with $2 \mathrm{M} \mathrm{KCl}$, and $30 \%$ sucrose solutions as described previously. Activator activity of the extract was estimated with fibrin plates.

The results obtained are presented in Tables 2 and 3 . The figure in the tables indicates the average value of lysis areas of two points observed on two different plates.

A remarkable fibrinolytic activity was observed on standard plates in kidney extract with $\mathrm{KCl}$ and sucrose solution, but no activity was observed on heated plates. The tissue activator activity of kidney parenchyma was disappeared after consecutive administration of MMC, although the change in activity of kidney pelvis was not remarkable even after MMC injection. In all cases, no lysis was observed with the extract from heart, lung and liver on both standard and heated plates.

3. Effect of MMC on the tissue inhibitor activity.

The influence of MMC on the plasmin inhibitor in kidney parenchyma was estimated before and after the consecutive administration.

MMC of $0.5 \mathrm{mg} / \mathrm{kg}$ was daily injected intravenously into 3 rabbits for 12 days. On the 15th day after starting the administration animals were bled to death, and kidney was taken out. The tissue inhibitor was extracted as described previously. Equal parts of the solution and 100 units $/ \mathrm{ml}$ plasmin were admixed, and $0.03 \mathrm{ml}$ of the admixture was dropped on fibrin plates. Then, the lysis area was compared with that from $0.03 \mathrm{ml}$ of 50 units $/ \mathrm{ml}$ plasmin on the standard fibrin plates.

Table 4.

Per cent inhibition against plasmin by kidney tissue inhibitor

\begin{tabular}{c|c|c}
\hline \multirow{3}{*}{ MMC group } & Rabbit No. & Per cent inhibition \\
\hline 13 & 79 \\
& 14 & 65 \\
Control group & 15 & 100 \\
& 16 & 100 \\
& 17 & 100 \\
\hline
\end{tabular}

The percent inhibition against plasmin is presented in Table 4. It is shown that the inhibitory action in MMC administered group is not higher than that of the control group. Therefore, the disapperance of tissue activator after MMC 
administration can not be explained by the increasing inhibitory action in kidney parenchyma.

4. Reversal of the tissue activator disappearance after ceasing MMC administration.

In order to know whether the decreased activator activity of kidney parenchyma is reversed, the following experiments were made. MMC of $0.5 \mathrm{mg} / \mathrm{kg}$ was daily injected intravenously into 4 rabbits for 3 days. Two animals out of 4 were sacrificed 24 hours after the last injection. The remained 2 were sacrificed 7 days after the last injection. The another 2 rabbits were used as control. The activator activity of kidney parenchyma was compared in the 3 groups. The results obtained are presented in Table 5. Twentyfour hours after the last injection, activator activity of kidney parenchyma was disappeared completely, but it reappeared 7 days after the last administration. These results showed that the reversible change of the activity in kidney parenchyma was produced by MMC administration to rabbits.

Table 5.

Reversible change of the fibrinolytic activity of kidney parenchyma after MMC administration

\begin{tabular}{l|c|c|c}
\hline & Rabbit No. & \multicolumn{2}{|c}{ Solution used } \\
\hline & 6 & $30 \%$ Sucrose & $2 \mathrm{M} \mathrm{KCl}$ \\
\hline Control & 7 & $117 \mathrm{~mm}^{2}$ & $166 \mathrm{~mm}^{2}$ \\
& 64 & 96 \\
\hline 24 hrs. after* & 18 & 0 & 0 \\
the last inj. & 19 & 0 & 0 \\
\hline 7 days after* & 20 & 31 & 37 \\
the last inj. & 21 & 27 & 40 \\
\hline
\end{tabular}

* $0.5 \mathrm{mg} / \mathrm{kg} / \mathrm{day}$ MMC was intravenously injected for 3 days.

\section{DISCUSSION}

MMC is an antitumor fraction isolated from the culture broth of a streptomyces caespitosus(13). Although this fraction has a marked inhibitory effect on various tumors(14,15), it sometimes produces a bleeding tendency by consecutive administration of a large amount to animals ${ }^{(16)}$ and patients(17). A decrease of leucocytes and blood platelets was not always sufficient to explain the bleeding tendency.

Recently the relationship between the bleeding tendency and the plasmin activity was discussed among some investigators. Okamoto, $\mathrm{S}$. et al reported 
that high activity of plasmin in blood was distinctively accompanied with the marked oozing in $\operatorname{dog}^{(18)}$. Thus, it was examined by the authors whether MMC causes a hyperplasminic state which associated with bleeding tendency in patients and animals as well.

The experimental results obtained indicated that the hyperplasminic state in blood and a reversible disappearance of tissue plasminogen activator in kidney parenchyma were both produced by consecutive administration of MMC to rabbits. Inhibitor activity of kidney parenchyma, however, was not increased in these cases.

Results of disappearance of tissue activator may suggest two possibilities; the first is the releasing of the tissue activator from cells, the second is the suppression of the activator production in cells by MMC administration. But the hyperplasminemia with MMC may support the possible releasing of the plasminogen activator to blood from tissue cells. On the other hand, the reversal of the decreased tissue activator after ceasing the administration of MMC may imply the active participation of the activator production to the phenomena observed here.

\section{SUMMRAY}

1. A long continued hyperplasminemia was produced by the consecutive administration of Mitomycin $\mathrm{C}$ to rabbits.

2. An activator activity was observed in kidney parenchyma and kidney pelvis when the activator was extracted from fresh tissue with $2 \mathrm{M} \mathrm{KCl}$ or $30 \%$ sucrose.

3. The activator activity of kidney parenchyma was completely disappeared after administration of Mitomycin $\mathrm{C}$, while variation of the activity of pelvis was not significant even after the administration. The disappearance of activator activity was not explained by the increasing inhibitory action in kidney parenchyma.

4. The recovery of the activator activity of kidney parenchyma was well demonstrated several days after ceasing the administration of Mitomycin $\mathrm{C}$.

\section{REFERENCES}

1. Biggs, R., Macfarlane, R. G. and Philling, J.: Lancet, 252: 402, 1947.

2. Soulier, J. P. and Koupernik, C.: . Le Sang, 19: 362, 1948.

3. Von Kaula, K. N.: Circulation, 17: 187, 1958. 4. Weiner, M., Redisch, W. and Steele, J. M.: Proc. Soc. Exp. Biol. Med., 98: 755,
1958.

5. Tillett, W. S.: Bact. Rev. 2: 161, 1938, 
6. Gelheim, E. B. et al: Proc. Soc. Exper. Biol. and Med., 71: 138, 1949.

7. Lewis, J. H. and Ferguson, J. H.: J. Clin Invest., 29: 486, 1950.

8. Astrup, T. and Muellertz, S.: Arch. Biochem., 40: 346, 1952.

9. Lassen, M.: Acta Physiol. Scandinav., 27: 371, 1952.

10. Okamoto, U. and Takada, Y.: Keio J. Med. 13: 107, 1964.

11. Gram, H. C.: J. Biol. Chem., 49: 297, 1921, cited from Bennhold, H. et al, Die Eiweisskoerper des Blutplasma, 1938.

12. Astrup, T. and Albrechtsen, O. K.: Seand, J. Clin. Lab. Invest., 9: 233, 1957.

13. Wakaki, S. et al: Antibioties and Chemotherapy, 8: 223, 1958.

14. Sugiura, K.: Gann, 50: 251, 1959.

15. Sugiura, K.: Cancer Research, 19: 436, 1959.

16. Yamada, M.: Chemotherapy, 8: 305, 1960.

17. Shimada, N. et al, in press.

18. Okamoto, S., Nakajima, T., Okamoto, U. et al: Keio J. Med., 8: 247, 1959. 